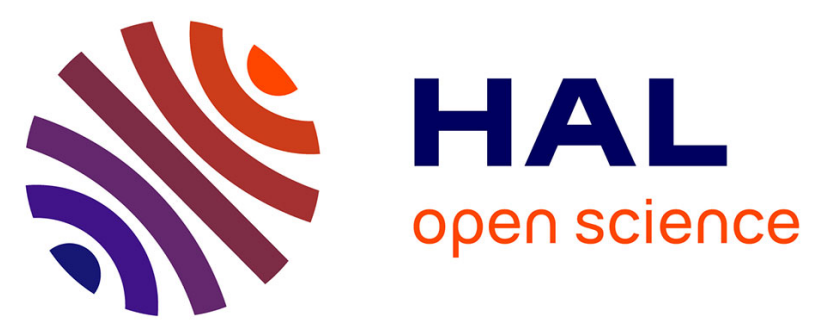

\title{
LOCAL STRUCTURE OF THE CuCu (EDTA) (H2O)2, 2H2O AMORPHOUS COMPLEX : A JOINT MAGNETIC, LAXS, AND MOLECULAR MECHANICS INVESTIGATION
}

\author{
A. Mosset, J. Devillers, Pierre Lecante, Jean Galy, E. Coronado, D. Beltran, \\ M. Drillon
}

\section{To cite this version:}

A. Mosset, J. Devillers, Pierre Lecante, Jean Galy, E. Coronado, et al.. LOCAL STRUCTURE OF THE $\mathrm{CuCu}$ (EDTA) (H2O)2, 2H2O AMORPHOUS COMPLEX: A JOINT MAGNETIC, LAXS, AND MOLECULAR MECHANICS INVESTIGATION. Journal de Physique Colloques, 1985, 46 (C8), pp.C8-661-C8-664. 10.1051/jphyscol:19858107 . jpa-00225149

HAL Id: jpa-00225149 https://hal.science/jpa-00225149

Submitted on 1 Jan 1985

HAL is a multi-disciplinary open access archive for the deposit and dissemination of scientific research documents, whether they are published or not. The documents may come from teaching and research institutions in France or abroad, or from public or private research centers.
L'archive ouverte pluridisciplinaire HAL, est destinée au dépôt et à la diffusion de documents scientifiques de niveau recherche, publiés ou non, émanant des établissements d'enseignement et de recherche français ou étrangers, des laboratoires publics ou privés. 


\title{
LOCAL STRUCTURE OF THE CUCu(EDTA) $\left(\mathrm{H}_{2} \mathrm{O}\right)_{2}, 2 \mathrm{H}_{2} \mathrm{O}$ AMORPHOUS COMPLEX :
} A JOINT MAGNETIC, LAXS, AND MOLECULAR MECHANICS INVESTIGATION

\author{
A. Mosset, J. Devillers ${ }^{\star \star}$, P. Lecante, J. Galy, E. Coronado , D. Beltran \\ and M. Dri11on $\star \star$ \\ Laboratoire de Chimie de Coordination du CNRS, 205 Route de Narbonne, \\ 31400 Toulouse, France \\ * Universidad de Valeneia, Quimica Inorganica, Burjasot, VaZencia, Spain \\ * Ecole Nationale Supémieure de Chimie, Département Science des Matériaux, \\ 67008 Strasbourg, France \\ $\star \star \star$ Laboratoixe des IMRCP, UA au CNRS $n^{\circ} 470$, 118 Route de Narbonne, \\ 31400 Toulouse, France
}

Rêsumé - L'ordre local dans le matériau amorphe $\mathrm{CuCu}(\mathrm{EDTA})\left(\mathrm{H}_{2} \mathrm{O}\right)_{2}, 2 \mathrm{H}_{2} \mathrm{O}$ est êtudiế par diffusion des rayons $X$ aux grands angles (LAXS) et par la mécanique moléculaire. Trois conformations énergétiquement équivalentes sont mises en évidence. Deux d'entre elles participent à la structure de la phase amorphe.

\begin{abstract}
The short range order in the amorphous $\mathrm{CuCu}(\mathrm{EDTA})\left(\mathrm{H}_{2} \mathrm{O}\right)_{2}, 2 \mathrm{H}_{2} \mathrm{O}$ is studied by Large Angle X-ray Scattering (LAXS) and molecular mechanics. Three conformations of the complex molecule are shown to be energetically equivalent, two of which are simultaneously present in the amorphous material.
\end{abstract}

Due to their ability to provide outstanding models for experimental and theoretical investigations, the structurally one-dimensional compounds have been thoroughly investigated.

A series of polymeric compounds, $\mathrm{MM}^{\prime}(\mathrm{EDTA})\left(\mathrm{H}_{2} \mathrm{O}\right)_{4}, 2 \mathrm{H}_{2} \mathrm{O}$ with $\mathrm{MM}^{\prime}=\mathrm{Co}$, Ni, $\mathrm{Mn}, \mathrm{Cd} .$. have been investigated both in the crystalline and in the amorphous state, and their magnetic versus structural properties established (1-4). The amorphous $\mathrm{CuCu}(\mathrm{EDTA})\left(\mathrm{H}_{2} \mathrm{O}\right)_{2}, 2 \mathrm{H}_{2} \mathrm{O}$ term exhibits a different behaviour, $1 . e$. a magnetic susceptibility following a Curie $1 \mathrm{aw}$ between $4 \mathrm{~K}$ and $300 \mathrm{~K}$, imp1ying no magnetic coupling of the Cu(II) ions suggesting a local structure built up by dimeric entities $\left(\mathrm{H}_{2} \mathrm{O}\right) \mathrm{Cu}(\mathrm{EDTA}) \mathrm{Cu}\left(\mathrm{H}_{2} \mathrm{O}\right)$ as in the crystalline phase (5).

A LAXS (Large Angle X-ray Scattering) study has been performed giving the typical experimental radial distribution curve indicated in Figure 1 (full line). It has not been possible to fit such curve using the molecular model extracted from the crystal structure.

Investigation by molecular mechanics was then decided in order to find some "reasonable" molecular conformations, i.e. of similar energy and easy to reach. This has been realized with the help of the sophisticated program MM2 by Allinger et al. (6) within the assumption that in the molecule the two fused-ring moieties were rather rigid, at least around the copper atoms. 


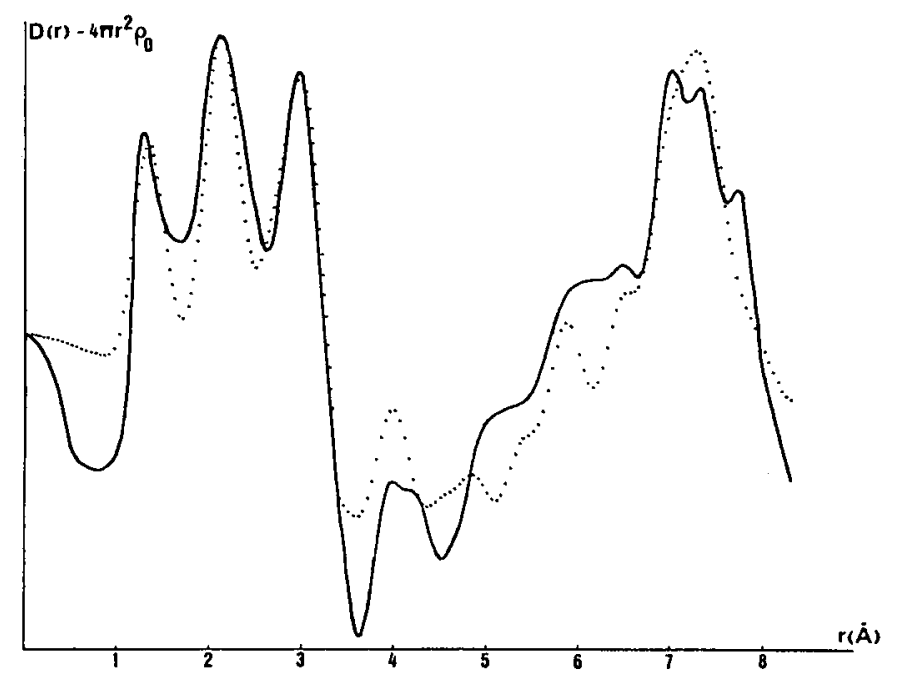

Figure 1. Comparison between experimental Ifull

line) and theoretical (dotted line) RDF.

Using the "driver" facility of the program, we moved to the dihedral angles $\theta_{1}$ $(\mathrm{Cu}(1)-\mathrm{N}(1)-\mathrm{C}(1)-\mathrm{C}(2))$ and $\theta_{2}(\mathrm{C}(1)-\mathrm{C}(2)-\mathrm{N}(2)-\mathrm{Cu}(2))$ and optimized the constraint energy while the other geometrical parameters were left to adjust to the minimization requirements.

For the purpose of comparison, the conformation found in the crystal was allowed to "relax", i.e. to minimize similarly its constraint energy, thus freeing the isolated molecule from the distorsions caused by the packing forces. The geometry did not change much and the constraint energy converged on the value $18.84 \mathrm{kcal}$.mole $\mathrm{e}^{-1}$ for the conformation $1\left(\theta_{1}=65.4^{\circ}\right.$ and $\left.\theta_{2}=-64.1^{\circ}\right)$ (Figure 2).

Two conformations are found very close in energy: conformation $2\left(\theta_{1}=63.6^{\circ}\right.$, $\left.\theta_{2}=-178.9^{\circ}, E_{c}=18.92 \mathrm{kcal} . \mathrm{mole}^{-1}\right)$ and conformation $3\left(\theta_{1}=179.4^{\circ}, \theta_{2}=\right.$ $\left.-178.1^{\circ}, \mathrm{E}_{\mathrm{c}}=19.22 \mathrm{kcal} . \mathrm{mole} \mathrm{e}^{-1}\right)$.

In order to examine if these conformations were accessible, the rotation barriers around the $\mathrm{N}(1)-\mathrm{C}(1)$ and $\mathrm{C}(1)-\mathrm{C}(2)$ bonds were estimated by simulation. For $\theta_{1}=63^{\circ}$ (fixed) the barrier around $C(1)-C(2)$ was found to be $5.6 \mathrm{kcal} . \mathrm{mole}^{-1}$ while for $\theta_{2}=120^{\circ}$ (variable) and for $\theta_{2}=180^{\circ}$ (fixed) the barrier around $N(1)-C(1)$ was $5.8 \mathrm{kcal}$. mole $e^{-1}$ for $\theta_{1}=120^{\circ}$ (variable) too.

These results indicate a posstble way - two steps at least - which allows conformational transformation with low energy consumption.

Several combinations of these three conformations were tested. The best fit was obtained using conformations 2 and 3 . In no case is the broad peak centred at $r$ $\cong 7 \AA$ explained. It was then thought of building a model implying a stacking of the 


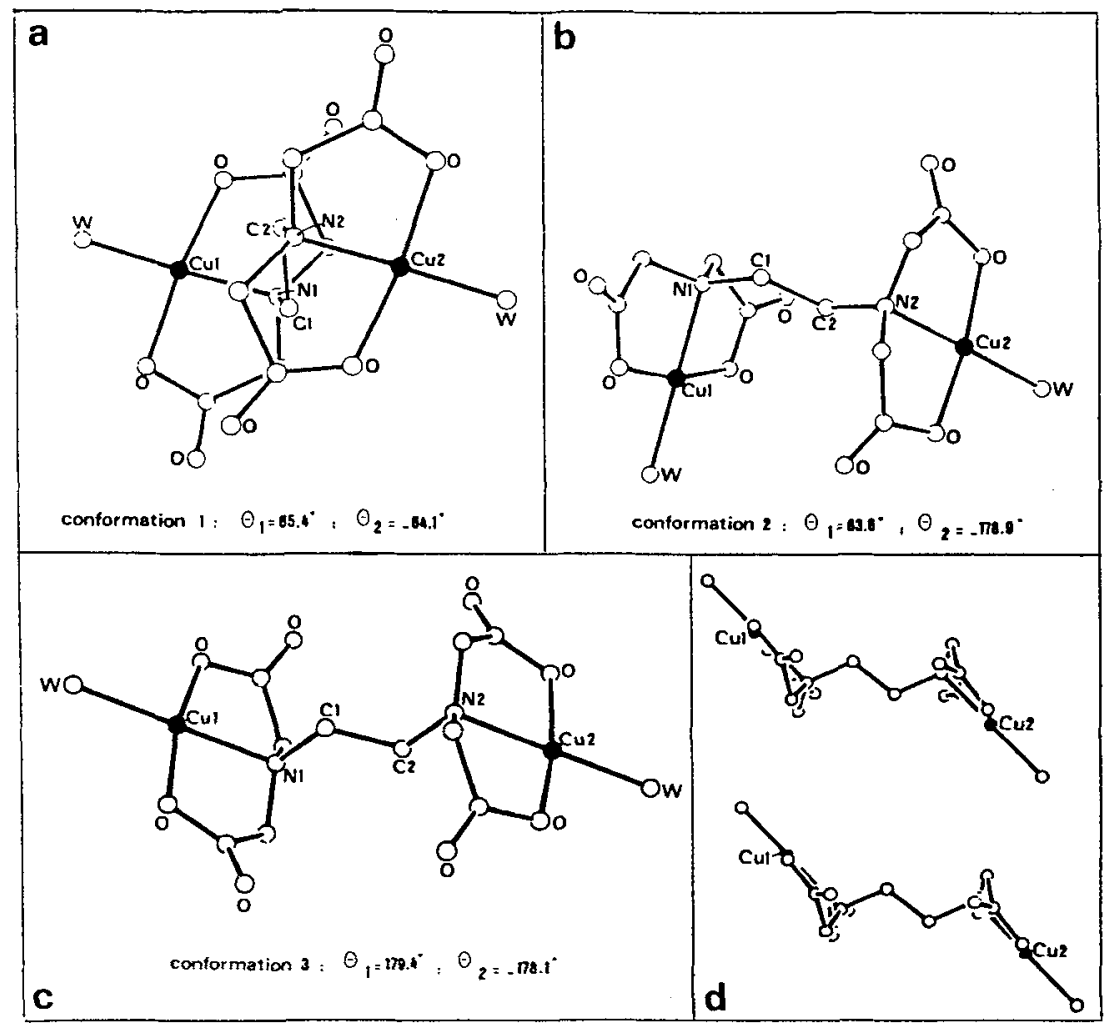

Figure 2. ORTEP drawings of preferred conformations for the $\mathrm{Cu}_{2} E D T A\left(\mathrm{H}_{2} \mathrm{O}\right)_{2}$ dimer.

molecules in conformation 3. This assumption has been tested by calculating the constraint energy and the optimal relative disposal of two molecules. A stabilization energy due to attractive Van der Waals forces of $2.1 \mathrm{kcal}^{\text {mole }} \mathrm{e}^{-1}$ is found for the stacking pictured in Figure 2-d.

The final model proposed, corresponding to the theoretical RDF (Figure 1 , dotted line) consists of three stacked molecules in conformation 3 and one in conformation 2 .

Acknowledgements : E.C. and D.B. thank the C.A.I.C.Y.T. for financial support under grant $2930 / 83$.

\section{REFERENCES}

(1) M. Drillon, J.C. Gianduzzo and R. Georges (1983), Phys. Lett. 96A, 413.

(2) M. Drillon, M. Coronado, D. Beltran and R. Georges (1983), Chem. Phys. 79, 449. 
(3) A. Mosset, J. Galy, E. Coronado, M. Drillon and D. Beltran (1983), J. Am. Chem. Soc. 106, 2864.

(4) E. Coronado, M. Drillon, D. Beltran and J.C. Bernier (1984), Inorg. Chem. 23, 4000 .

(5) T.V. Filippova, T.N. Polynuva, M.A. Porai-Koshits, N.V. Novozhilova and L.I. Martinenko (1973), Zh. Strukt. Khim. 14, 280.

(6) N.L. Allinger and Y.H. Yuh (1977), NMR, QCPE Program No. 395, Indiana University. 